Supporting Information for Inorganic Chemistry

\title{
Dinuclear Transition Metal-Terpyridine Complexes with a Dithienylcyclopentene Bridge Directed toward Molecular Electronic Applications
}

Yu-Wu Zhong, Neus Vila, Jay C. Henderson, Samuel Flores-Torres, and Héctor D.

Abruña*

Department of Chemistry and Chemical Biology, Baker Laboratory, Cornell University, Ithaca, New York, 14853-1301

E-mail: hda1@cornell.edu

Table of Contents

1. Synthetic Procedures and Characeterization

2. UV/Vis spectra and Irradiation Experiments

3. Cyclic Voltammetric Analysis

4. Determination of open-to-closed conversion efficiency of bis-tpy ligand 9 


\section{Synthetic Procedures and Characterization}

General. All reactions were carried out under an atmosphere of dry nitrogen using standard Schlenk techniques. Dry tetrahydrofuran was distilled from Sodium/benzophenone and other solvents (analytical grade) were used without further purification. NMR spectra were recorded in the designated solvent on a Varian 300 or Varian 400 spectrometer. Spectra are reported in ppm values from residual protons of the deuterated solvent for ${ }^{1} \mathrm{H}$ NMR $(\delta 7.26 \mathrm{ppm}$ for chloroform and $1.92 \mathrm{ppm}$ for acetonitrile) or from solvent carbon for ${ }^{13} \mathrm{C}$ NMR ( $\delta 77.00 \mathrm{ppm}$ for chloroform). MALDI-TOF positive ion data were obtained with a Waters MALDI micro MX mass spectrometer run in reflection mode. Compounds (tpy) $\mathrm{C}_{6} \mathrm{H}_{4} \mathrm{Br}-4(\mathbf{5}),{ }^{1} \mathrm{Ru}(\mathrm{tpy}) \mathrm{Cl}_{3},{ }^{2}$ Os(tpy) $\mathrm{Cl}_{3},{ }^{3} \mathrm{Fe}\left(\right.$ tpy) $\mathrm{Cl}_{2},{ }^{4}$ and $\mathrm{Co}($ tpy $) \mathrm{Cl}_{2}{ }^{5}$ were prepared according to known procedures.

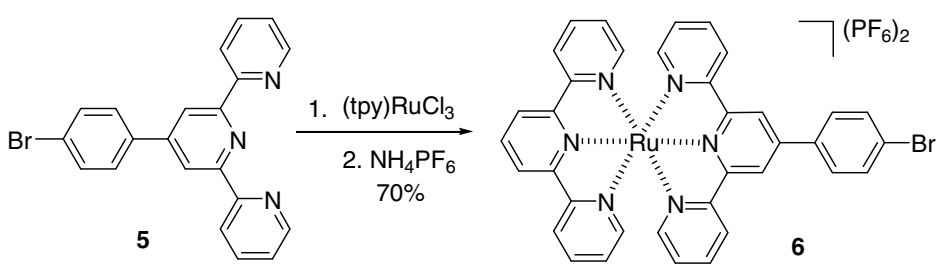

$\left(2,2^{\prime}: 6^{\prime}, 2^{\prime \prime}\right.$-Terpyridyl)(4'-(4-bromophenyl)-2,2' $: 6^{\prime}, 2^{\prime \prime}$-terpyridyl) ruthenium(II) hexafluorophophate (6), $[\mathbf{R u}(\mathbf{t p y})(\mathbf{5})]\left(\mathbf{P F}_{\mathbf{6}}\right)_{2}$. A mixture of (tpy) $\mathrm{RuCl}_{3}(1.35 \mathrm{~g}, 3.06$ mmol) and $5(1.30 \mathrm{~g}, 3.30 \mathrm{mmol})$ in $30 \mathrm{~mL}$ of ethylene glycol was heated under microwave irradiation for 15 minutes. After cooling, the mixture was poured into $30 \mathrm{~mL}$ of water. After filtration, $3.0 \mathrm{~g}$ of $\mathrm{NH}_{4} \mathrm{PF}_{6}$ was added to precipitate the crude product, which was purified by flash column chromatography on silica gel to give $2.17 \mathrm{~g}$ of $\mathbf{6}$ in $80 \%$ yield. ${ }^{1} \mathrm{H}$ NMR $\left(400 \mathrm{MHz}, \mathrm{CD}_{3} \mathrm{CN}\right): \delta 7.17(\mathrm{~m}, 4 \mathrm{H}), 7.35(\mathrm{~d}, J=5.60 \mathrm{~Hz}, 2 \mathrm{H})$, $7.43(\mathrm{~d}, J=5.60 \mathrm{~Hz}, 2 \mathrm{H}), 7.93(\mathrm{~m}, 6 \mathrm{H}), 8.11(\mathrm{~d}, J=8.40 \mathrm{~Hz}, 2 \mathrm{H}), 8.42(\mathrm{t}, J=8.40 \mathrm{~Hz}$, $1 \mathrm{H}), 8.50(\mathrm{~d}, J=8.20 \mathrm{~Hz}, 2 \mathrm{H}), 8.63(\mathrm{~d}, J=8.20 \mathrm{~Hz}, 2 \mathrm{H}), 8.75(\mathrm{~d}, J=8.40 \mathrm{~Hz}, 2 \mathrm{H})$, $8.97(\mathrm{~s}, 2 \mathrm{H})$.

\footnotetext{
${ }^{1}$ Wang, J.; Hanan, J. S. Synlett 2005, 1251.

2 Sullivan, B, P.; Calvert, J. M.; Meyer, T. J. Inorg. Chem. 1980, 19, 1404.

3 Barton, S. C.; Kim, H.-H.; Binyamin, G.; Zhang, Y.; Heller, A. J. Phys. Chem. B 2001, 105, 11917.

${ }^{4}$ Broomhead, J. A.; Dwyer, F. P. Aust. J. Chem. 1961, 14, 250.

${ }^{5}$ Morgan, G. T.; Burstall, F. H. J. Chem. Soc. 1932, 20.
} 


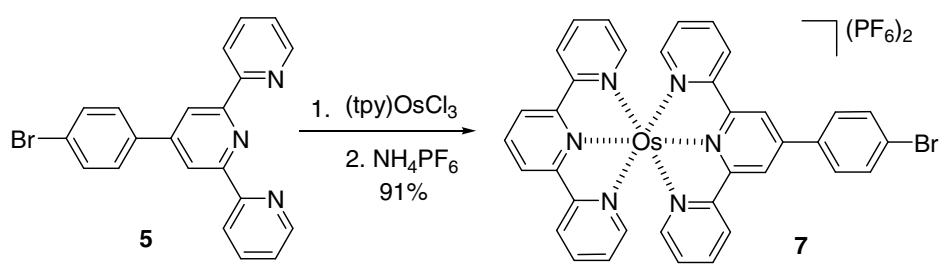

$\left(2,2^{\prime}: 6^{\prime}, 2^{\prime \prime}\right.$-Terpyridyl)(4' -(4-bromophenyl)-2,2' :6', $2^{\prime \prime}$-terpyridyl)

osmium(II)

hexafluorophophate (7), $[\mathbf{O s}(\mathbf{t p y})(\mathbf{5})]\left(\mathbf{P F}_{\mathbf{6}}\right)_{2}$. A mixture of (tpy) $\mathrm{OsCl}_{3}(212 \mathrm{mg}, 0.40$ $\mathrm{mmol}$ ) and $\mathbf{5}$ (156 mg, $0.40 \mathrm{mmol})$ in $8 \mathrm{~mL}$ of ethylene glycol was refluxed for 12 hours. After cooling, the mixture was poured into $30 \mathrm{~mL}$ of aqueous solution containing 600 $\mathrm{mg}$ of $\mathrm{NH}_{4} \mathrm{PF}_{6}$. The resulting black precipitate was collected through filtration and washing with water and ether. Recrystallization of the sample in acetonitrile/ether gave $394 \mathrm{mg}$ of 7 in $91 \%$ yield. ${ }^{1} \mathrm{H}$ NMR $\left(300 \mathrm{MHz}, \mathrm{CD}_{3} \mathrm{CN}\right): \delta 7.08(\mathrm{~m}, 4 \mathrm{H}), 7.21(\mathrm{~d}, J=$ $5.70 \mathrm{~Hz}, 2 \mathrm{H}), 7.26(\mathrm{~d}, J=5.70 \mathrm{~Hz}, 2 \mathrm{H}), 7.78\left(\mathrm{AB}, J_{\mathrm{AB}}=7.80 \mathrm{~Hz}, 4 \mathrm{H}\right), 7.94(\mathrm{~m}, 3 \mathrm{H})$, $8.07(\mathrm{~d}, J=8.70 \mathrm{~Hz}, 2 \mathrm{H}), 8.46(\mathrm{~d}, J=8.40 \mathrm{~Hz}, 2 \mathrm{H}), 8.58(\mathrm{~d}, J=8.10 \mathrm{~Hz}, 2 \mathrm{H}), 8.75$ (d, $J=8.10 \mathrm{~Hz}, 2 \mathrm{H}), 8.98$ (s, 2H). ${ }^{13} \mathrm{C}$ NMR $\left(75 \mathrm{MHz}, \mathrm{CD}_{3} \mathrm{CN}\right): \delta 121.18,123.48,125.30$, 125.52, 125.67, 128.60, 128.66, 130.98, 133.42, 135.96, 136.39, 138.74, 138.82, 147.03, $153.34,153.56,155.88,156.12,160.78$.

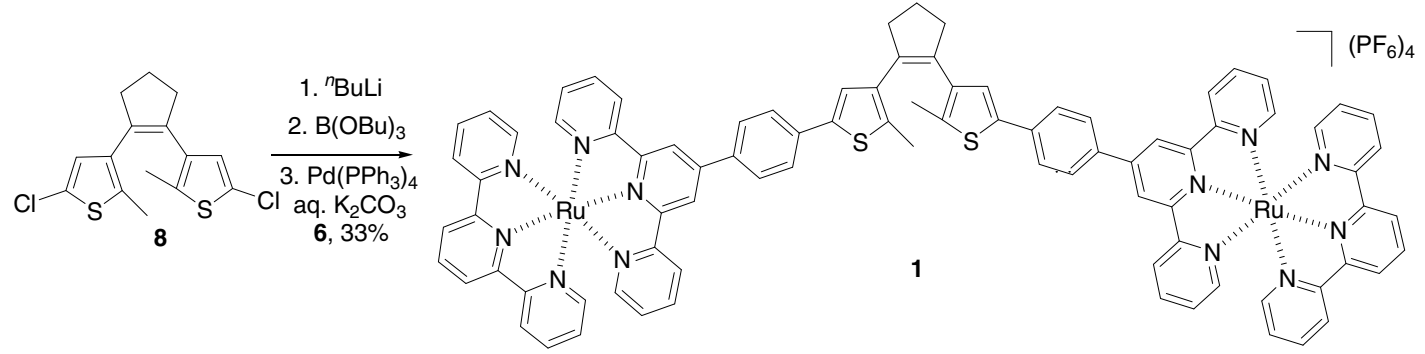

To a solution of $8(33 \mathrm{mg}, 0.10 \mathrm{mmol})$ in THF $(2.0 \mathrm{~mL})$ was added $0.13 \mathrm{~mL}$ of $1.6 \mathrm{M}$ $n$-Butyllithium in $n$-Hexane at room temperature. Ten mins later, $0.081 \mathrm{~mL}$ of tributyl borate $(0.30 \mathrm{mmol})$ were added. After stirring for 1 hour, the resulting reddish solution was used directly for the following addition. To another Schlenk flask filled with $5 \mathrm{~mL}$ of degassed DMSO was added 6 (190 mg, $0.2 \mathrm{mmol})$ and $\mathrm{Pd}\left(\mathrm{PPh}_{3}\right)_{4}(11 \mathrm{mg}, 0.010$ mmol). After stirring for 15 minutes, $0.50 \mathrm{~mL}$ of $2 \mathrm{M}$ saturated aqueous sodium carbonate solution $(1.0 \mathrm{mmol})$ and $0.060 \mathrm{~mL}$ of ethylene glycol were added. The solution was stirred for another 15 minutes under bubbling, before the temperature was raised to $60{ }^{\circ} \mathrm{C}$. To the mixture was then added the above prepared reddish solution in one portion. The mixture was stirred at $80{ }^{\circ} \mathrm{C}$ for 24 hours. After cooling, $3 \mathrm{~mL}$ of 
acetonitrile were added. The mixture was added into $50 \mathrm{~mL}$ of saturated aqueous $\mathrm{KPF}_{6}$ solution under stirring. The red precipitate was collected through filtration and washed with water and ethyl ether successively. Flash column chromatography on silica gel $\left(\mathrm{CH}_{3} \mathrm{CN} / \mathrm{H}_{2} \mathrm{O} /\right.$ saturated aqueous $\left.\mathrm{KNO}_{3}, 100 / 10 / 5\right)$ of the sample afforded $70 \mathrm{mg}$ of $\mathbf{1}$ as a red solid in $33 \%$ yield. ${ }^{1} \mathrm{H}$ NMR $\left(400 \mathrm{MHz}, \mathrm{CD}_{3} \mathrm{CN}\right): \delta 2.10(\mathrm{~s}, 6 \mathrm{H}, 2 \mathrm{Me}), 2.20(\mathrm{~m}$, $2 \mathrm{H}, \mathrm{CH}_{2} \mathrm{CH}_{2} \mathrm{CH}_{2}$ ), 2.95 (t, $J=7.20 \mathrm{~Hz}, 4 \mathrm{H}, \mathrm{CH}_{2} \mathrm{CH}_{2} \mathrm{CH}_{2}$ ), 7.17 (t, $J=6.40 \mathrm{~Hz}, 8 \mathrm{H}$ ), $7.35(\mathrm{~d}, J=5.60 \mathrm{~Hz}, 4 \mathrm{H}), 7.43(\mathrm{~d}, J=5.60 \mathrm{~Hz}, 4 \mathrm{H}), 7.51$ (s, 2H, 2CH), $7.93(\mathrm{~m}, 12 \mathrm{H})$, $8.24(\mathrm{~d}, J=8.40 \mathrm{~Hz}, 4 \mathrm{H}), 8.42(\mathrm{t}, J=8.40 \mathrm{~Hz}, 2 \mathrm{H}), 8.49$ (d, $J=8.20 \mathrm{~Hz}, 4 \mathrm{H}), 8.65$ (d, $J$ $=8.20 \mathrm{~Hz}, 4 \mathrm{H}), 8.75(\mathrm{~d}, J=8.40 \mathrm{~Hz}, 4 \mathrm{H}), 9.02$ (s, 4H). MALDI-MS: 1979.20 [M $\left.\mathrm{PF}_{6}\right]^{3+}$ (calc. 1979.18), 1834.22 $\left[\mathrm{M}-2 \mathrm{PF}_{6}\right]^{2+}$ (calc. 1834.22), 1689.26 $\left[\mathrm{M}-3 \mathrm{PF}_{6}\right]^{+}($calc. 1689.25), $1209.30\left[\mathrm{M}-\mathrm{Ru}-\mathrm{tpy}-4 \mathrm{PF}_{6}\right]^{+}$(calc. 1209.29). Anal. Calcd for $\mathrm{C}_{87} \mathrm{H}_{64} \mathrm{~F}_{24} \mathrm{~N}_{12} \mathrm{P}_{4} \mathrm{Ru}_{2} \mathrm{~S}_{2}$ : C, 49.20; H, 3.04; N, 7.91. Found: C, 48.79; H, 3.26; N, 7.02.

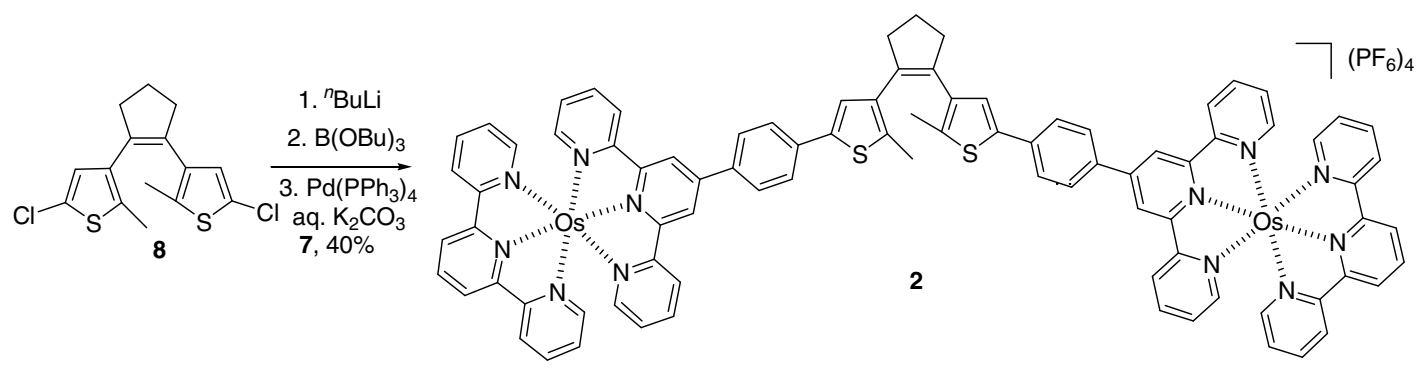

To a solution of $8(33 \mathrm{mg}, 0.10 \mathrm{mmol})$ in THF $(2.0 \mathrm{~mL})$ was added $0.13 \mathrm{~mL}$ of $1.6 \mathrm{M}$ $n$-Butyllithium in $n$-Hexane at room temperature. Ten minutes later, $0.081 \mathrm{~mL}$ of tributyl borate $(0.30 \mathrm{mmol})$ were added. After stirring for 1 hour, the resulting reddish solution was used directly for the following addition. To another Schlenk flask filled with $5 \mathrm{~mL}$ of degassed DMSO was added $7(220 \mathrm{mg}, 0.2 \mathrm{mmol})$ and $\mathrm{Pd}\left(\mathrm{PPh}_{3}\right)_{4}(11 \mathrm{mg}$, $0.010 \mathrm{mmol}$ ). After stirring for $15 \mathrm{mins}, 0.50 \mathrm{~mL}$ of $2 \mathrm{M}$ saturated aqueous sodium carbonate solution $(1.0 \mathrm{mmol})$ and $0.060 \mathrm{~mL}$ of ethylene glycol was added. The solution was stirred for another 15 mins under bubbling, before the temperature was raised to $60{ }^{\circ} \mathrm{C}$. To the mixture was then added the above prepared reddish solution in one portion. The mixture was stirred at $80{ }^{\circ} \mathrm{C}$ for 24 hours. After cooling, $3 \mathrm{~mL}$ of acetonitrile were added. The mixture was added into $50 \mathrm{~mL}$ of saturated aqueous $\mathrm{KPF}_{6}$ solution under stirring. The red precipitate was collected through filtration and washed with water and ethyl ether successively. Flash column chromatography on silica gel $\left(\mathrm{CH}_{3} \mathrm{CN} / \mathrm{H}_{2} \mathrm{O} /\right.$ saturated aqueous $\left.\mathrm{KNO}_{3}, 100 / 10 / 5\right)$ of the sample afforded $92 \mathrm{mg}$ of 2 as 
a red solid in $40 \%$ yield. ${ }^{1} \mathrm{H}$ NMR $\left(300 \mathrm{MHz}, \mathrm{CD}_{3} \mathrm{CN}\right): \delta 2.08(\mathrm{~s}, 6 \mathrm{H}, 2 \mathrm{Me}), 2.18(\mathrm{~m}$, $2 \mathrm{H}, \mathrm{CH}_{2} \mathrm{CH}_{2} \mathrm{CH}_{2}$ ), 2.95 (t, $\left.J=7.50 \mathrm{~Hz}, 4 \mathrm{H}, \mathrm{CH}_{2} \mathrm{CH}_{2} \mathrm{CH}_{2}\right), 7.08$ (t, $\left.J=6.60 \mathrm{~Hz}, 8 \mathrm{H}\right)$, $7.21(\mathrm{~d}, J=5.40 \mathrm{~Hz}, 4 \mathrm{H}), 7.28(\mathrm{~d}, J=5.40 \mathrm{~Hz}, 4 \mathrm{H}), 7.50(\mathrm{~s}, 2 \mathrm{H}, 2 \mathrm{CH}), 7.78(\mathrm{q}, J=7.80$ $\mathrm{Hz}, 8 \mathrm{H}), 7.92(\mathrm{~m}, 6 \mathrm{H}), 8.19(\mathrm{~d}, J=8.40 \mathrm{~Hz}, 4 \mathrm{H}), 8.46(\mathrm{~d}, J=7.80 \mathrm{~Hz}, 4 \mathrm{H}), 8.62(\mathrm{~d}, J=$ $7.80 \mathrm{~Hz}, 4 \mathrm{H}), 8.75(\mathrm{~d}, J=8.40 \mathrm{~Hz}, 4 \mathrm{H}), 9.03$ (s, 4H). MALDI-MS: 2157.33 [M - PF 6 $2 \mathrm{H}]^{3+}$ (calc. 2157.28), 2012.36 [M - 2PF $\left.-2 \mathrm{H}\right]^{2+}$ (calc. 2012.31), 1867.38 [M-3PF $2 \mathrm{H}]^{+}$(calc. 1867.35), $1298.36\left[\mathrm{M}-\mathrm{Os}-\mathrm{tpy}-4 \mathrm{PF}_{6}-1 \mathrm{H}\right]^{+}$(calc. 1298.34).

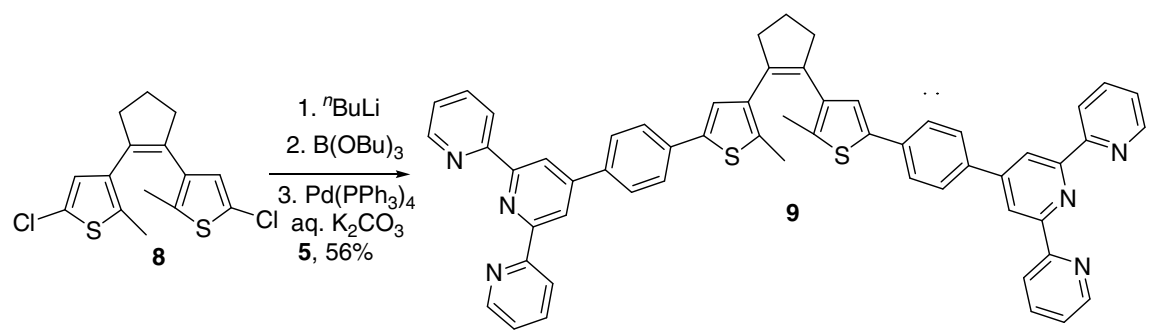

1,2-Bis-(5-(4"''-(4'-(2,2':6',2'-terpyridyl)phenyl)-2-methylthien-3-yl))cyclopentene

(9). To a solution of 8 (33 mg, $0.10 \mathrm{mmol})$ in THF (2.0 mL) was added $0.13 \mathrm{~mL}$ of 1.6 M $n$-butyllithium in $n$-hexane at room temperature. Ten mins later, $0.081 \mathrm{~mL}$ of tributyl borate $(0.30 \mathrm{mmol})$ were added. After stirring for 1 hour, the resulting reddish solution was used directly for the following addition. To another Schlenk flask filled with $5 \mathrm{~mL}$ of degassed DMSO was added $5(78 \mathrm{mg}, 0.2 \mathrm{mmol})$ and $\mathrm{Pd}\left(\mathrm{PPh}_{3}\right)_{4}(11 \mathrm{mg}, 0.010$ mmol). After stirring for 15 minutes, $0.50 \mathrm{~mL}$ of $2 \mathrm{M}$ saturated aqueous sodium carbonate solution $(1.0 \mathrm{mmol})$ and $0.060 \mathrm{~mL}$ of ethylene glycol were added. The solution was stirred for another 15 mins under bubbling, before the temperature was raised to $60{ }^{\circ} \mathrm{C}$. To the mixture was then added the above prepared reddish solution in one portion. The mixture was stirred at $80{ }^{\circ} \mathrm{C}$ for 12 hours. After cooling, $50 \mathrm{~mL}$ of toluene were added to dilute the mixture, followed by washing with water $(10 \mathrm{~mL} \times 3)$ and brine. Recrystallization of the concentrated residue in dichloromethane/ethyl acetate afforded $23 \mathrm{mg}$ of 9 as a grey solid in $56 \%$ yield. ${ }^{1} \mathrm{H}$ NMR $\left(300 \mathrm{MHz}, \mathrm{CDCl}_{3}\right): \delta 2.05$ (s, $6 \mathrm{H}, 2 \mathrm{Me}$ ), $2.10\left(\mathrm{~m}, 2 \mathrm{H}, \mathrm{CH}_{2} \mathrm{CH}_{2} \mathrm{CH}_{2}\right), 2.90\left(\mathrm{t}, \mathrm{J}=7.20 \mathrm{~Hz}, 4 \mathrm{H}, \mathrm{CH}_{2} \mathrm{CH}_{2} \mathrm{CH}_{2}\right.$ ), 7.17 (s, 2H, 2CH), $7.35(\mathrm{~m}, 4 \mathrm{H}), 7.65(\mathrm{~d}, J=8.40 \mathrm{~Hz}, 4 \mathrm{H}), 7.80(\mathrm{~m}, 8 \mathrm{H}), 8.67(\mathrm{~d}, J=8.10 \mathrm{~Hz}$, $4 \mathrm{H}), 8.74(\mathrm{~d}, J=3.90 \mathrm{~Hz}, 4 \mathrm{H}), 8.76(\mathrm{~s}, 4 \mathrm{H}) .{ }^{13} \mathrm{C} \mathrm{NMR}\left(100 \mathrm{MHz}, \mathrm{CDCl}_{3}\right): \delta 14.80(2 \mathrm{C}$, 2Me), $23.27\left(\mathrm{CH}_{2} \mathrm{CH}_{2} \mathrm{CH}_{2}\right), 38.77$ (2C, 2CCH$), 118.61$ (4C), 121.54 (4C), 124.00 (4C), 124.74 (2C), 125.85 (4C), 127.91 (4C), 134.91 (2C), 135.39 (2C), 135.43 (2C), 136.91 (2C), 137.03 (4C), 137.11 (2C), 139.22 (2C), 149.33 (4C), 149.69 (2C), 156.13 (4C), 
156.45 (4C). Anal. Calcd for $\mathrm{C}_{57} \mathrm{H}_{42} \mathrm{~N}_{6} \mathrm{~S}_{2}$ : C, 78.23; H, 4.84; N, 9.60. Found: C, 77.97; H, 4.59; N, 9.32.

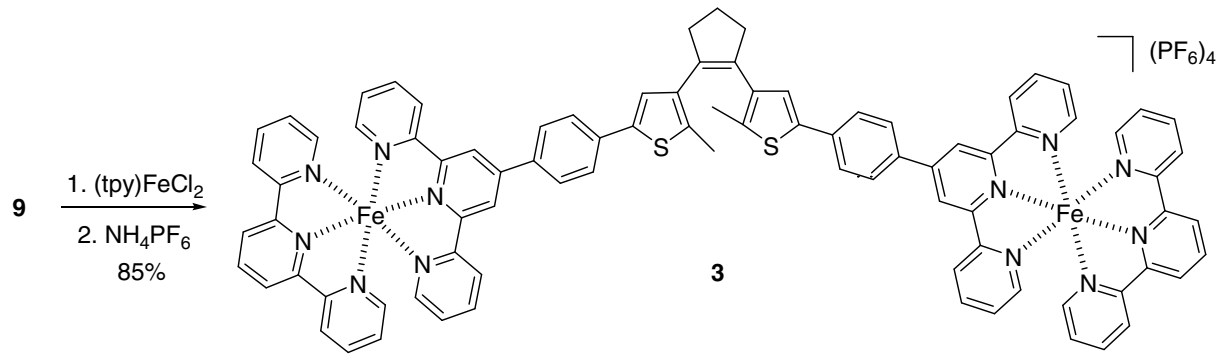

A solution of ligand $9(8.7 \mathrm{mg}, 0.010 \mathrm{mmol})$ in $2.0 \mathrm{~mL}$ of dichloromethane was added to a suspension of (tpy) $\mathrm{FeCl}_{2}(7.2 \mathrm{mg}, 0.020 \mathrm{mmol})$ in $2.0 \mathrm{~mL}$ of methanol. The mixture was stirred at room temperature for 15 minutes. Then a solution of $\mathrm{NH}_{4} \mathrm{PF}_{6}(32 \mathrm{mg}$, $0.20 \mathrm{mmol}$ ) was added. The deep purple precipitate was collected after filtration and washed with methanol and ether $\left(17 \mathrm{mg}, 85 \%\right.$ yield). ${ }^{1} \mathrm{H}$ NMR $\left(300 \mathrm{MHz}, \mathrm{CD}_{3} \mathrm{CN}\right): \delta$ $2.16\left(\mathrm{~m}, 6 \mathrm{H}, 2 \mathrm{Me}+\mathrm{CH}_{2} \mathrm{CH}_{2} \mathrm{CH}_{2}\right), 3.00\left(\mathrm{t}, J=7.50 \mathrm{~Hz}, 4 \mathrm{H}, \mathrm{CH}_{2} \mathrm{CH}_{2} \mathrm{CH}_{2}\right), 7.09$ (m, $12 \mathrm{H}), 7.21(\mathrm{~d}, J=4.80 \mathrm{~Hz}, 4 \mathrm{H}), 7.86(\mathrm{~s}, 2 \mathrm{H}, 2 \mathrm{CH}), 7.90(\mathrm{~m}, 8 \mathrm{H}), 8.02(\mathrm{~d}, J=8.40 \mathrm{~Hz}$, 4H), $8.37(\mathrm{~d}, J=8.40 \mathrm{~Hz}, 4 \mathrm{H}), 8.48(\mathrm{~m}, 4 \mathrm{H}), 8.63(\mathrm{~d}, J=7.80 \mathrm{~Hz}, 4 \mathrm{H}), 8.70(\mathrm{td}, J=$ 8.10, $2.10 \mathrm{~Hz}, 2 \mathrm{H}), 8.91(\mathrm{dd}, J=8.10,3.90 \mathrm{~Hz}, 4 \mathrm{H}), 9.22(\mathrm{~s}, 4 \mathrm{H})$.

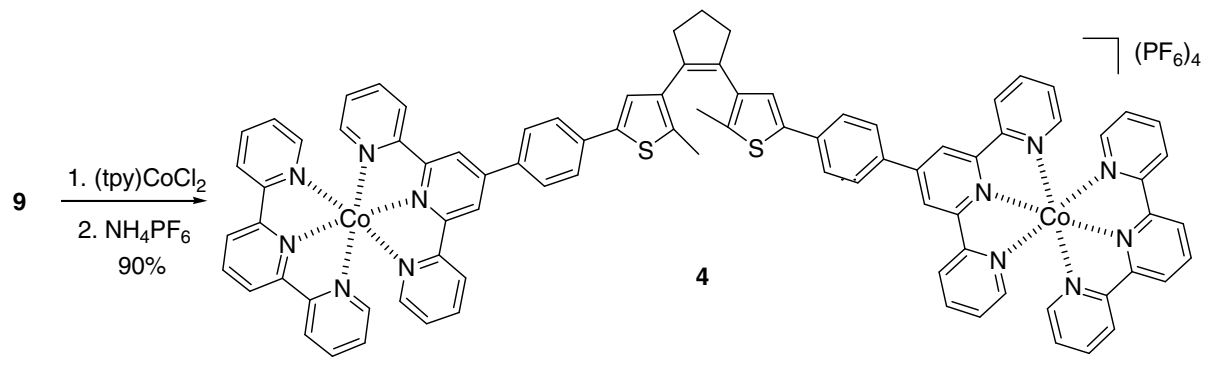

A solution of ligand $9(87 \mathrm{mg}, 0.10 \mathrm{mmol})$ in $5 \mathrm{~mL}$ of dichloromethane was added to a suspension of (tpy) $\mathrm{CoCl}_{2}(73 \mathrm{mg}, 0.20 \mathrm{mmol})$ in $10 \mathrm{~mL}$ of methanol. The mixture was stirred at room temperature for 15 minutes. Then a solution of $\mathrm{NH}_{4} \mathrm{PF}_{6}(320 \mathrm{mg}, 2.0$ mmol) was added. The orange precipitate was collected after filtration and washed with methanol and ether $\left(180 \mathrm{mg}, 90 \%\right.$ yield). MALDI-MS: $1894.32\left[\mathrm{M}-\mathrm{PF}_{6}+1 \mathrm{H}\right]^{3+}$ (calc. 1894.25), $1748.33\left[\mathrm{M}-2 \mathrm{PF}_{6}\right]^{2+}$ (calc. 1748.28), $1604.37\left[\mathrm{M}-3 \mathrm{PF}_{6}+1 \mathrm{H}\right]^{+}($calc. 1604.32), 1166.37 [M - Co - tpy - 4PF $]^{+}$(calc. 1166.32). Anal. Calcd for $\mathrm{C}_{87} \mathrm{H}_{64} \mathrm{Co}_{2} \mathrm{~F}_{24} \mathrm{~N}_{12} \mathrm{P}_{4} \mathrm{~S}_{2}$ : C, 51.24; H, 3.16; N, 8.24. Found: C,50.98; H, 2.99; N, 7.95. 


\section{UV/Vis spectra and Irradiation Experiments}

General. All optical ultraviolet-visible (UV/vis) absorption spectra were obtained using a HP 8453 diode array spectrometer at room temperature in acetonitrile, with typical 1.0 cm quartz cells. Irradiation experiments were carried out using a $200 \mathrm{~W}$ Mercury Xenon lamp as the light source and the specific wavelength was selected with the monochromator.
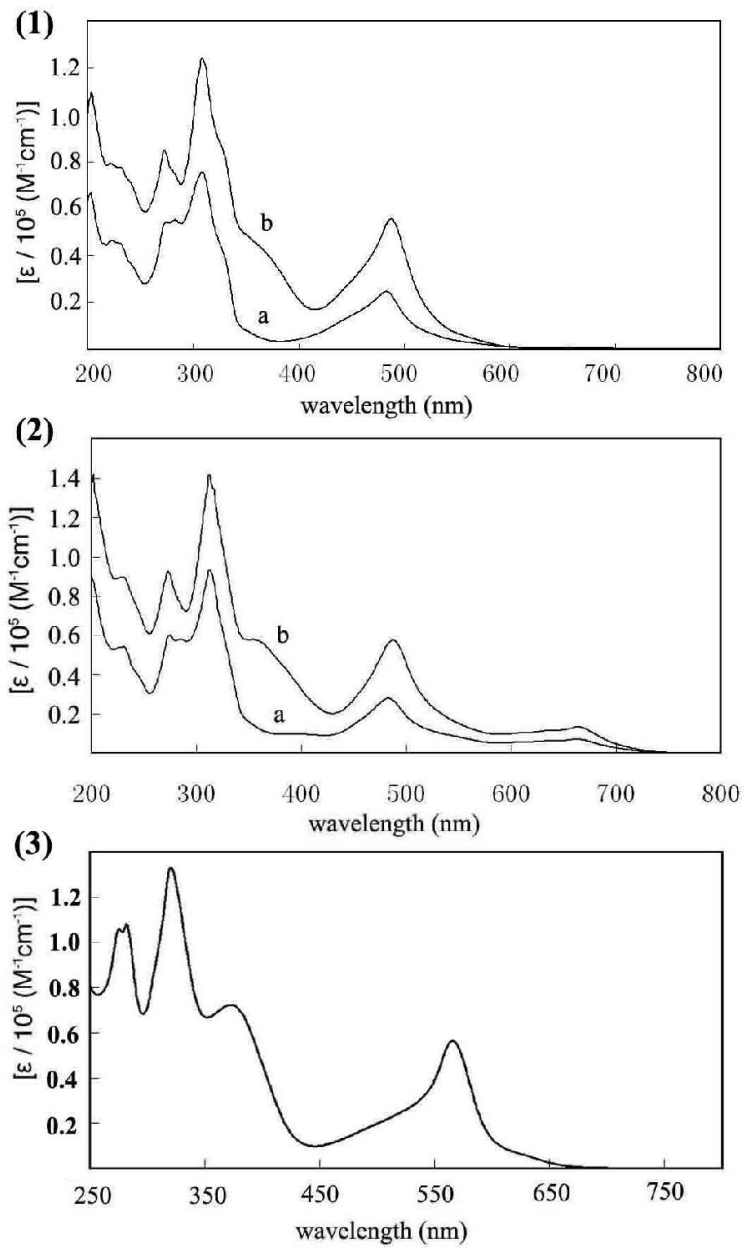

Figure S1. UV/Vis absorption spectra of (1)a the mono-Ru(II) complex 6, (1)b the di-Ru(II) Complex 1, (2)a the mono-Os(II) complex 7, (2)b the di-Os(II) Complex 2 , and (3) the di-Fe(II) complex 3 at a concentration of $1 \times 10^{-5} \mathrm{M}$ in acetonitrile. 
Table S1. UV/Vis absorption maxima and molar absorption coefficients of the compounds studied.

\begin{tabular}{ll}
\hline Compound & $\lambda_{\max } / \mathrm{nm}\left(\varepsilon / 10^{5} \mathrm{M}^{-1} \mathrm{~cm}^{-1}\right)$ \\
\hline $\mathbf{6}$ & $274(1.4), 284(1.4), 310(1.9), 485(0.6)$ \\
$\mathbf{7}$ & $275(1.5), 313(2.3), 485(0.7), 665(0.2)$ \\
$\mathbf{8}$ & $240^{a}$ \\
Cyclized-8 & $276,444^{a}$ \\
$\mathbf{1}$ & $274(2.1), 310(3.1), 370(1.0), 489(1.4)$ \\
$\mathbf{2}$ & $274(2.3), 313(3.5), 360(1.4), 489(1.4), 666(0.3)$ \\
$\mathbf{3}$ & $276(1.1), 282(1.1), 322(1.3), 376(0.7), 567(0.6)$ \\
$\mathbf{4}$ & $283(0.7), 318(0.7), 388(0.3), 519(0.03)$ \\
Cyclized-4 & $283(0.7), 319(0.8), 380(0.2), 600(0.15)$ \\
\hline${ }^{a}$ See ref. 6. &
\end{tabular}

${ }^{6}$ Lucas, L. N.; de Jong, J. J. D.; van Esch, J. H.; Kellogg, R. M.; Feringa, B. L. Eur. J. Org. Chem. 2003, 155 . 


\section{Cyclic Voltammetric Analysis}

General. All cyclic voltammetry (CV) were taken using an Epsilon (BAS) potentiostat. All measurements were carried out with a $0.3 \mathrm{mM}$ of the corresponding complex in acetonitrile, a glassy carbon as the working electrode, a platinum wire as the counter electrode, with a $\mathrm{Ag} / \mathrm{AgCl}$ reference electrode, at a scan rate of $100 \mathrm{mV} / \mathrm{s}$, and in $0.1 \mathrm{M}$ of $\mathrm{Bu}_{4} \mathrm{NClO}_{4}$ as the supporting electrolyte.
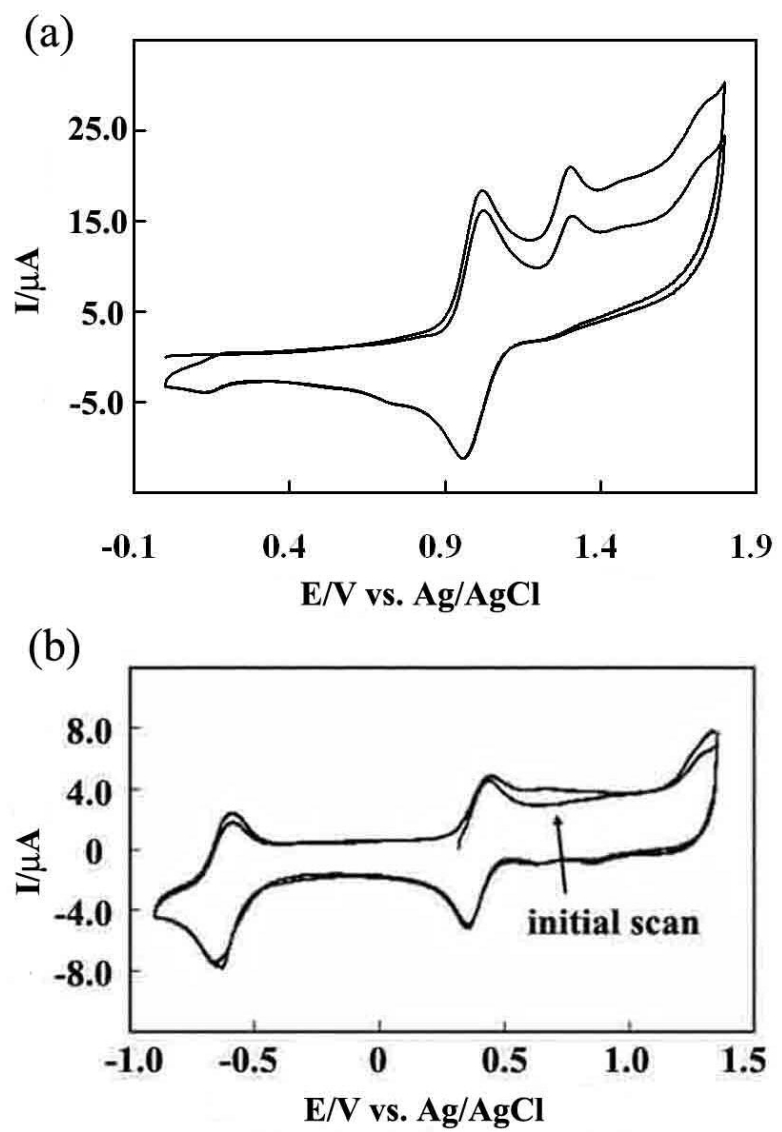

Figure S2. Cyclic Voltammetry of (a) the bis-Os(II) Complex 2 and (b) the bis-Co(II) Complex 4. 
Table S2. Electrochemical data of investigated compounds ${ }^{a}$

\begin{tabular}{lll}
\hline Compound & Metal-based & DTE-based \\
\hline $\mathbf{6}$ & $1.33 \mathrm{Ru}(\mathrm{III}) / \mathrm{Ru}(\mathrm{II})$ & -- \\
$\mathbf{7}$ & $1.04 \mathrm{Os}(\mathrm{III}) / \mathrm{Os}(\mathrm{II})$ & -- \\
$\mathbf{1}$ & $1.35 \mathrm{Ru}(\mathrm{III}) / \mathrm{Ru}(\mathrm{II})$ & 1.22 (irrersible) $^{b}$ \\
$\mathbf{C y c l i z e d - 1}$ & $1.35 \mathrm{Ru}(\mathrm{III}) / \mathrm{Ru}(\mathrm{II})$ & $0.54,0.75$ \\
$\mathbf{2}$ & $0.98 \mathrm{Os}(\mathrm{III}) / \mathrm{Os}(\mathrm{II})$ & 1.31 (irrersible) $^{b}$ \\
$\mathbf{3}$ & $1.23 \mathrm{Fe}(\mathrm{III}) / \mathrm{Fe}(\mathrm{II})$ & 1.22 (irrersible $^{b}$ \\
$\mathbf{C y c l i z e d - 3}$ & $1.23 \mathrm{Fe}(\mathrm{III}) / \mathrm{Fe}(\mathrm{II})$ & $0.60,0.81$ \\
$\mathbf{4}$ & $0.39 \mathrm{Co}(\mathrm{III}) / \mathrm{Co}(\mathrm{II})$ & -- \\
& $-0.61 \mathrm{Co}(\mathrm{II}) / \mathrm{Co}(\mathrm{I})$ & \\
\hline
\end{tabular}

${ }^{a}$ All measurements were carried out with a $0.3 \mathrm{mM}$ of the corresponding complex in acetonitrile, a $\mathrm{Ag} / \mathrm{AgCl}$ reference electrode, a glassy carbon as the working electrode, a platinum wire as the counter electrode, at a scan rate of $100 \mathrm{mV} / \mathrm{s}$, and in $0.1 \mathrm{M}$ of $\mathrm{Bu}_{4} \mathrm{NClO}_{4}$ as the supporting electrolyte. Unless otherwise noted, the potential was reported as the $E_{1 / 2}$ value. ${ }^{b} E_{\text {anodic }}$ 


\section{Determination of open-to-closed conversion efficiency of bis-tpy ligand 9}

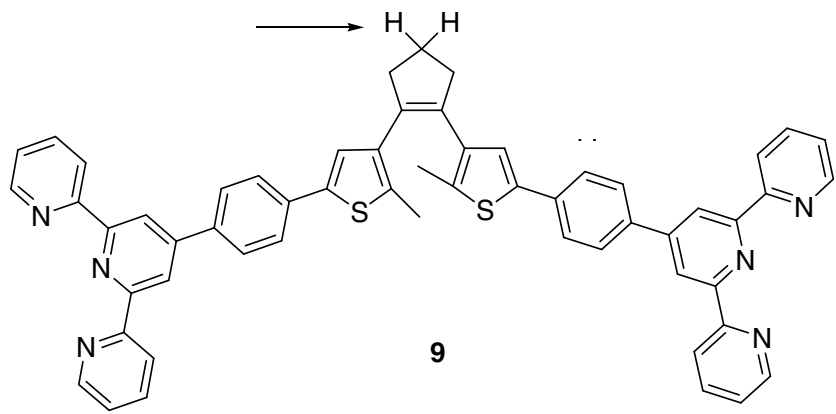

Figure S3. Bis-tpy ligand 9. The methylene group as denoted by arrow shows different chemical shift in the open and closed forms in ${ }^{1} \mathrm{H}$ NMR spectra.

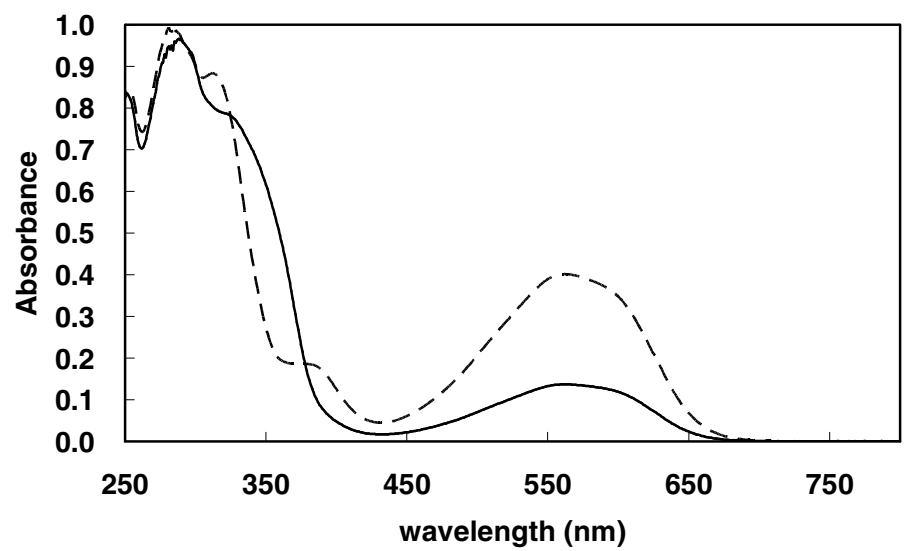

Figure S4. UV/Vis absorption spectra of 9 in acetonitrile with $34.9 \%$ (solid line) and quantitative (dashed line, photo stationary state) open-to-closed conversion.

Compound 9 ( $5 \mathrm{mg}$ in $0.5 \mathrm{~mL} \mathrm{D} \mathrm{D}_{8}$-THF) in an NMR tube was irradiated at $320 \mathrm{~nm}$ for 30 mins. Its ${ }^{1} \mathrm{H}$ NMR spectrum was then recorded as shown in Figure S6. The open-to-closed conversion efficiency of this sample was determined to be $34.9 \%$ by comparing the integration of the triplet at $\delta 2.94$ (2.78) and 2.59 (1.49), which corresponded to a methylene group of the cyclopentene ring (Figure S3) in the open and closed forms respectively. A drop of this sample was then diluted in $4 \mathrm{~mL}$ THF in a typical $1.0 \mathrm{~cm}$ quartz cell, and the corresponding absorption spectrum was shown in Figure S4 (solid line). The cell was irradiated at $320 \mathrm{~nm}$ for 5 minutes to the photo stationary state (dashed line), which corresponded to a quantitative open-to-closed conversion by comparing the absorbance at $560 \mathrm{~nm}(0.137$ and 0.401 respectively for the sample with $34.9 \%$ conversion and at the photo stationary state). 


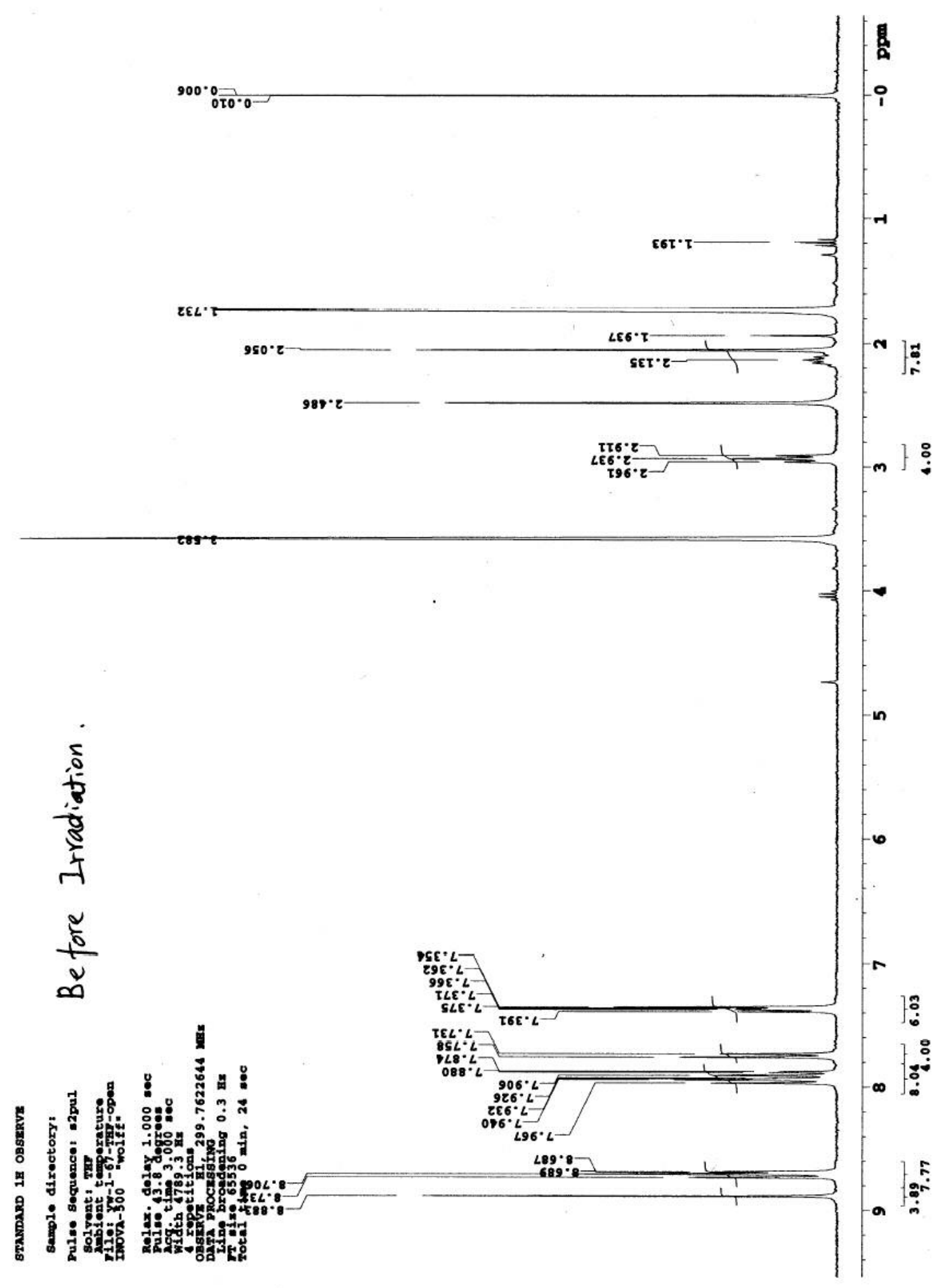

Figure S5. ${ }^{1} \mathrm{H}$ NMR (300 MHz, $\mathrm{D}_{8}$-THF) of 9 before irradiation. 


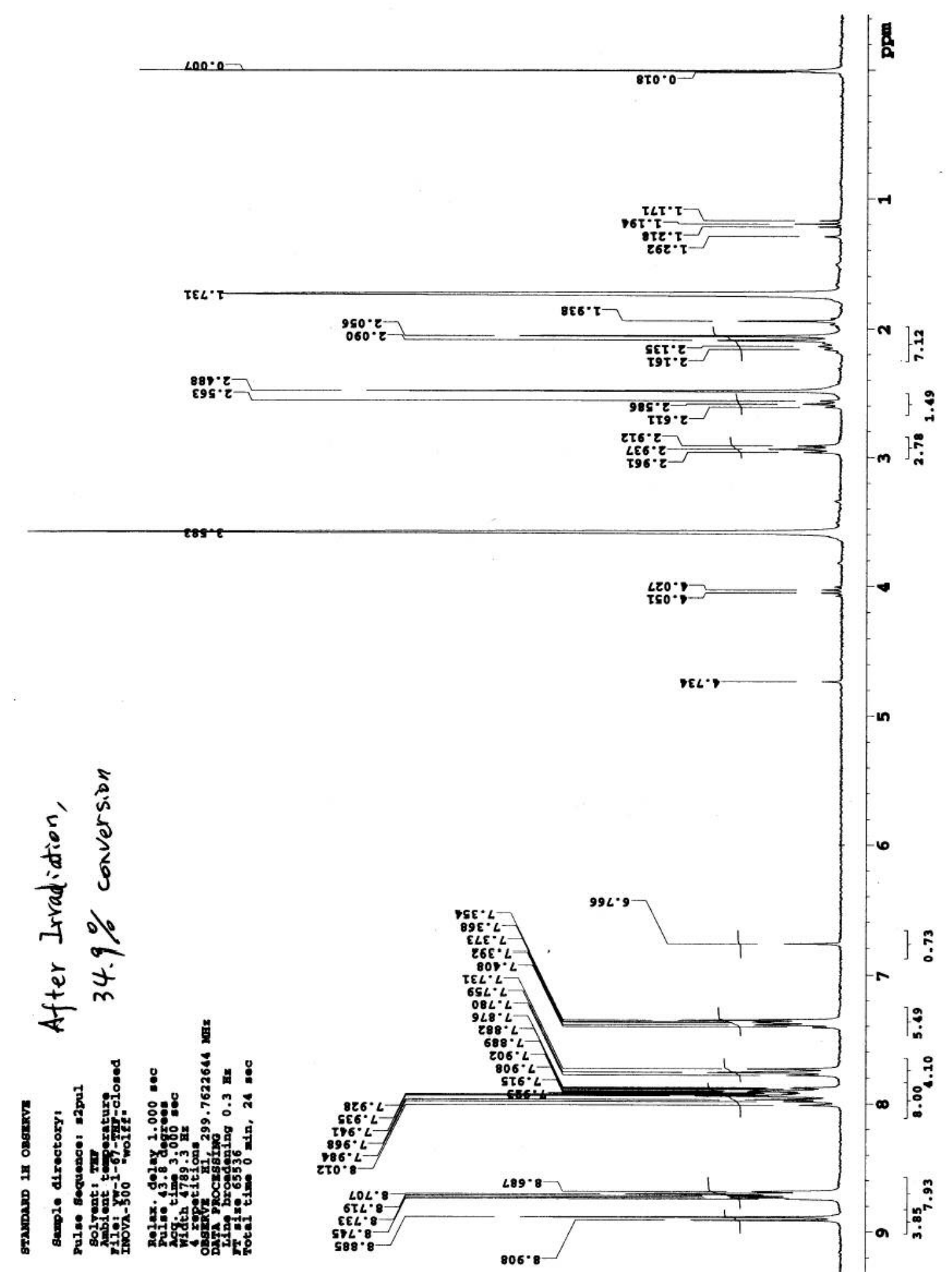

Figure S6. ${ }^{1} \mathrm{H}$ NMR $\left(300 \mathrm{MHz}, \mathrm{D}_{8}\right.$-THF) of 9 after irradiation at $320 \mathrm{~nm}$ to a $34.9 \%$ open-to-closed conversion. 